\title{
New finding of Parastasia vietnamensis Wada, 2008 (Coleoptera: Scarabaeidae: Rutelinae)
}

\author{
Новая находка Parastasia vietnamensis Wada, 2008 \\ (Coleoptera: Scarabaeidae: Rutelinae)
}

\author{
А.М. Прокофьев \\ A.M. Prokofiev
}

Institute for Ecology and Evolution, Russian Academy of Sciences, Leninsky prospect 33, Moscow 119071 Russia. Институт проблем экологии и эволюции РАН - ИПЭЭ, Ленинский проспект 33, Москва 119071, Россия.

КЕYWORDS. Rutelinae, Parastasia vietnamensis, redescription, Dalat Highlands, Vietnam.
КЛЮЧЕВЫЕ СЛОВА. Rutelinae, Parastasia vietnamensis, переописание, Далатское нагорье, Вьетнам.

ABSTRACT. Parastasia vietnamensis Wada, 2008 described by the unique holotype from Dalat Highlands (Lam Dong province, Vietnam) is rediscovered in the neighbouring parts of Khanh Hoa province; description of this specimen is given and characteristic of the species is corrected.

РЕЗЮМЕ. Parastasia vietnamensis Wada, 2008, описанная по единственному экземпляру с Далатского нагорья (пров. Ламдонг, Вьетнам), найдена повторно в пограничном районе соседней провинцией Кханьхоа. Приведено описание экземпляра; уточнена морфологическая характеристика вида.

Parastasia vietnamensis has been described recently by a single specimen collected in Lam Dong province, Vietnam [Wada, 2008]. It is a member of the Parastasia westwoodi-group [sensu Ohaus, 1934] sharing a number of the highly specialized traits though those are not wholly presented in some of the included species. In April 2012 I collected an additional specimen representing a new province record of this apparently very rare species, which shows slight differences from the original description. Because the latter contains not all of the important features of this species I believe pertinent to publish its redescription based on a newly collected specimen.

\section{Parastasia vietnamensis Wada, 2008} Figs 1-8

MATERIAL. $1 \sigma^{r}$, Vietnam, Khanh Hoa prov., Khan Vinh distr., approx. $2 \mathrm{~km}$ above felling, DT 723/652, $12^{\circ} 13.546^{\prime} \mathrm{N}$, $108^{\circ} 46.019^{\prime} \mathrm{E}$, alt. $877-879 \mathrm{~m}, 25-26.04 .2012$, on light, A.M. Prokofiev leg.

REDESCRIPTION. Male (Fig. 1). Length $11 \mathrm{~mm}$, greatest width $6 \mathrm{~mm}$. Oval, convex from above, moderately shining; elytra less shining than pronotum and pygidium because of microgranulations; head, propygidium and previous terga more or less alutaceous. Head blackish with cherry-brown tint; antennae with reddish-brown pedicel and blackish club; pronotum and elytra yellowish- to reddish-brown, elytra little darker; anterior and posterior borders of pronotum, scutellum, basal margin and sutural line of elytra narrowly margined by black; pygidium dark reddish-brow; underside, propygidium and previous terga dark-reddish-brown to black; legs yellowish- to reddish-brown, tarsi much more infuscated; tibial spines and spurs blackish; setosity pale-yellowish.

Anterior margin of clypeus broadly rounded, not thickened and very weakly reflexed, without any teeth or indentations; anterior angles indistinct. Clypeofrontal suture completely absent; clypeus and frons forming a single shield without any transition (Fig. 2); eye-canthus narrow, with outer margin straight. Clypeus finely rugopunctate, more densely at anterior margin; frontovertex finely punctate, laterally rugopunctate; dorsal surface of head dulled by microgranulations. Punctures bearing minute setae (less than halfdiameter of puncture in length). Mandibles straight, almost horizontal, with anterior margin nearly straight and anterolateral angle broadly rounded and only slightly reflexed (Fig. 2). Labrum transverse, anterior margin slightly convex, somewhat serrate. Galea having four large and slender teeth, three apical ones and a single basal one; apices acuminate. Last joint of mandibular palpi elongately securiform, with an oval depression in basal half of its outer margin.

Pronotum 1.8 times as broad as long, with maximum width at mid-length; anterior margin concave, with broad membranous border in the middle third; anterior angles strongly obtuse, broadly rounded; lateral margins indistinctly sinuate anteriorly and posteriorly; basal margin smoothly convex, indistinctly sinuate near the posterior angles; posterior angles obtuse, broadly rounded; basis completely unbordered. Punctation of pronotum large and coarse, umbilicate, slightly irregular, somewhat denser and smaller toward anterior angles; each puncture bearing minute seta (about $1 / 5$ of its diameter in length); microsculpture of pronotum very fine, much finer than on elytra or head.

Elytra scarcely longer than broad, coarsely and regularly punctate; punctures large, umbilicate, apparently devoid setae, becoming smaller toward sides and apices of elytra; punctate rows indistinguishable from the punctures of interspaces. Propygidium dull, densely microsculputed and closely punctated; punctures double, larger ones intermixed with fine and shallowly impressed ones; punctures becoming larger to distal margin of propygidium, where they bearing quite 
long setae (about twice longer than diameter of puncture); basal half of propygidium on each side with a pair of transversely elongated impressions, roughly microgranulated to transversely striated (Fig. 3); posteriormost spiracle on the same level as surface of propygidium. Pygidium nearly flat, with apex weakly truncated, whole surface completely covered with the reticulate, undulate, coalescing rugules and moderately short and sparse adpressed hairs.
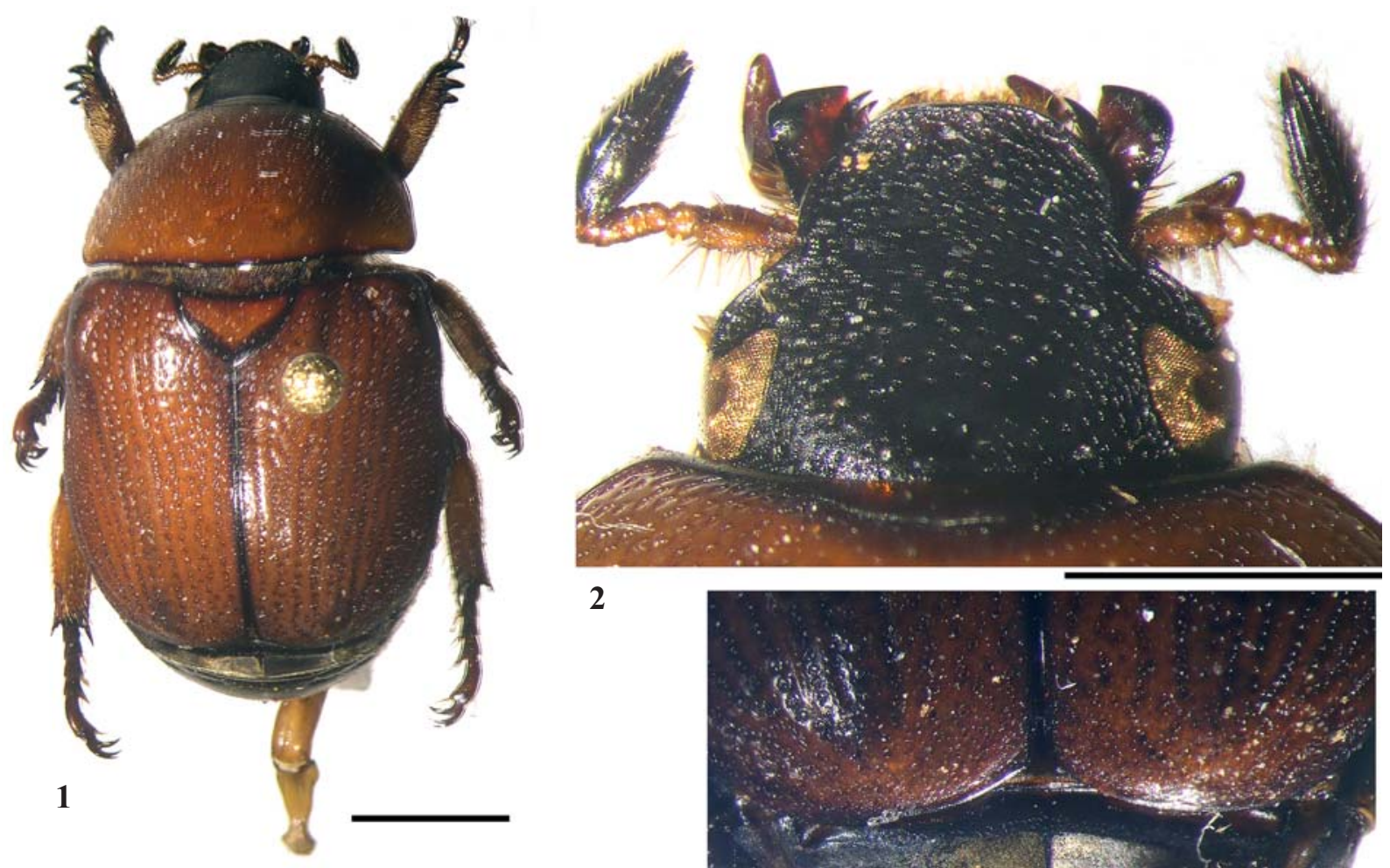

2
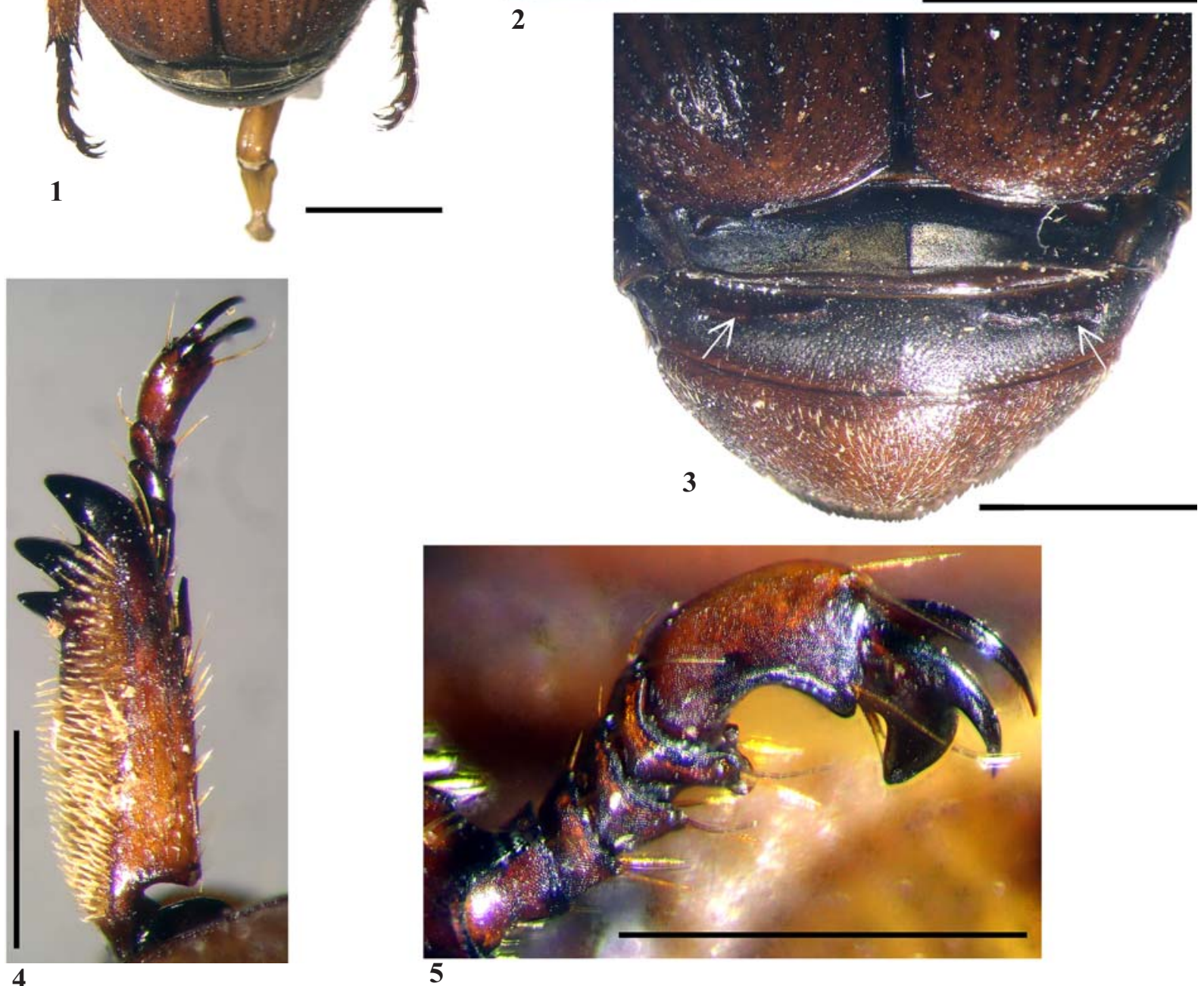

Figs 1-5. Parastasia vietnamensis, male: 1 - dorsal view; 2 - head and mandibles, dorsal view; 3 - propygidium and pygidium (paired lateral impressions arrowed); $4-$ fore tibia; $5-$ middle tarsus. Scale bars: $1-3 \mathrm{~mm} ; 2-5-1.5 \mathrm{~mm}$.

Рис. 1-5. Parastasia vietnamensis, самец: 1 - сверху; 2 - голова и мандибулы, сверху; 3 - пропигидий и пигидий (стрелками показаны парные боковые вдавления); $4-$ передняя голень; $5-$ средняя лапка. Масштаб: $1-3$ мм; $2-5-1.5$ мм. 
Prosternal process reduced to a small longitudinal swelling; mesometasternal process short, hardly surpassing middle coxae; sterna transversely rugulose and hairy on sides, finely and sparsely punctate, bare on disc; hairs long but quite sparse. Abdominal sternites transversely rugulose, with upper sides completely covered by short setae becoming minute mesially except a transverse row of setae just behind posterior margin of each sternite.

Fore tibia with internobasal angle acute; lateral teeth in apical third, closely spaced, perpendicular to the longitudinal axis of tibia; dorsolateral area with dense, brush-like, erect bristles (Fig. 4), this area sharply separated from rest of dorsal surface by a fine ridge. Fore tarsi with last joint moderately thickened, inner claw clefted, both lobes simply acuminate. Middle tibia ending by long spinuous process, having only weak traces of dorsolateral carina but with dense short and curved bristles on lateral surface and with a row of long bristles along dorsal and ventral margins. Joints of middle tarsi strongly shortened and thickened; last joint enlarged, bulbous, with outer claw deeply clefted, lower lobe broad and lobiform (Fig. 5). Hind tibia with apical margin produced into short spine, lacking dorsolateral carina; outer hind claw deeply clefted, both lobes slender and simply acuminate.

Parameres (Figs 6-8) symmetric, elongate (as long as phallobase), strongly contracted laterally, with membranous outgrowths on dorsal surface of their apices (Fig. 8).

Female unknown.

REMARKS. The newly discovered specimen well agrees with the original description of $P$. vietnamensis except the minor differences in the shape of the clypeus described as having "a pair of vague low upright teeth" [Wada, 2008: 8] in the holotype instead of smoothly rounded and lacking any traces of teeth on the anterior margin in my specimen. Also the microsetosity of the dorsal surface of head and the pronotum is not described for the holotype, but these setae are so small that they could be easily overlooked. The shape of the genitalia is identical in the holotype and in the newly discovered specimen. The shape of mandibles was not described by Wada [2008] but it appears to be very characteristic due to their chisel-shaped appearance with the nearly straight distal margin and the broadly rounded anterolateral corner instead of produced into sharp upturned tooth in all the other species within the genus.

$P$. vietnamensis undoubtedly belongs to the $P$. westwoodi-species group of Ohaus [1934] and Kuijten [1992] due to the absence of the clypeofrontal suture, the setose pygidium and the presence of the specialized setosity on the lateral surfaces of the fore and middle tibiae, the strongly thickened last joint of the middle tarsi and the lobiform lower lobe of the outer middle claw, and the general plan of the structure of the male genitalia including the presence of the apical membranous outgrowths of the parameres. In most of the characters this species is very similar to $P$. femorata Burmeister, 1844 from Java, but these species can be easily distinguished by the shape of parameres, which are much longer in $P$. vietnamensis (approximately equal to phallobase in length vs. much shorter). The only other member of this group also known from continental Asia, P. indica Ohaus, 1898 (northeastern India to Indo-China including North Vietnam),

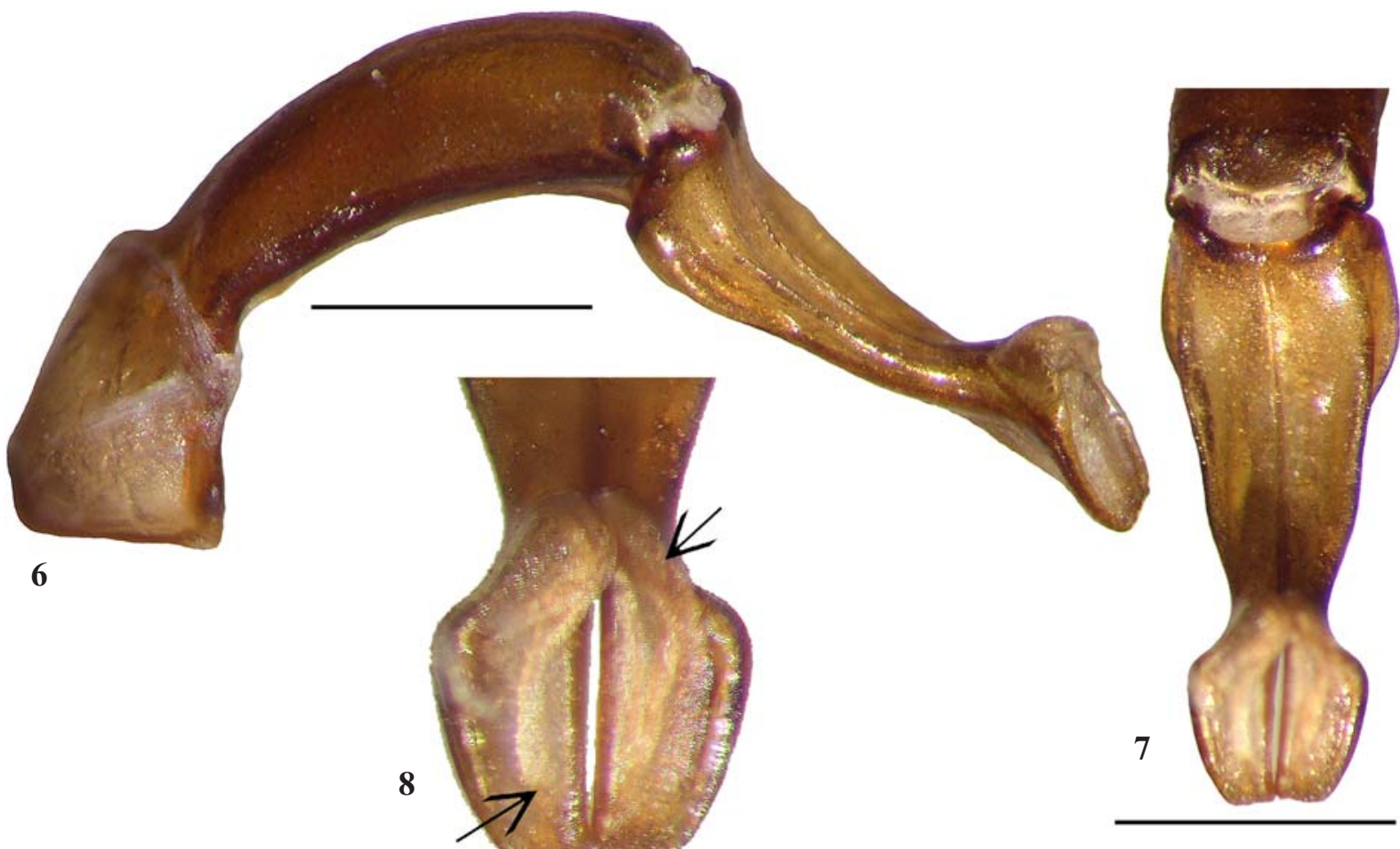

Figs 6-8. Parastasia vietnamensis, aedeagus: 6 - lateral view; 7 - dorsal view of the parameres; 8 - apices of the parameres (membranous outgrowths arrowed). Scale bars: 6-7-1 $\mathrm{mm} ; 8-0.5 \mathrm{~mm}$.

Рис. 6-8. Parastasia vietnamensis, эдеагус: 6 - сбоку; 7 - парамеры, сверху; 8 - вершины парамер (стрелками обозначены мембранозные выросты). Масштаб: 6-7-1 мм; $8-0.5$ мм. 
exhibits only partial characters of the $P$. westwoodigroup; it lacks the specialized setosity on the fore and middle tibiae, but has the equal and simply acuminated lobes of the outer middle claw and the different shape of the parameres, which are not expanded apically and lacking the membranous outgrowths. All the other members of this group are distributed from Malaysia, peninsular Thailand and Philippines eastward to New Guinea; all of them possess a distinctive shape of the male genitalia [Kuijten, 1992; Wada, 2008].

\section{References}

Kuijten P.J. 1978. Revision of the genus Parastasia in the IndoAustralian Region // Zoologische Verhandelingen. Vol.275. P.1-207.

Ohaus F. 1934. Coleoptera Lamellicornia, Fam. Scarabaeidae, Subfam. Rutelinae, 1 // Genera Insectorum. Vol.199. P.1-172. 6 pls. Wada K. 2008. Five new species of the genus [sic!] Parastasia westwoodi-group (Coleoptera, Scarabaeidae, Rutelinae) from the Oriental region // Kogane. Nr.9. P.1-10. 